\title{
11 Generating or receiving carbon leakages?
}

\author{
An examination of China's $\mathrm{CO}_{2}$ \\ emissions in Asia
}

Le Tuyet Vo and Yiyi Ju

\section{Introduction}

After opening up and economic reforms in 1978, China's development was remarkable with a gross domestic product (GDP) growth rate of almost $10 \%$ per year, and it became the world's second-largest economy. In 2018, China became the world's number-one export country and was second in imported goods. In the meantime, decades of rapid economic growth have dramatically expanded China's energy needs. As a result, China is now the world's largest $\mathrm{CO}_{2}$-generating country. China's fossil fuel consumption accounted for $87.6 \%$ of total energy consumption in 2014 (China Energy Group at Lawrence Berkeley National Laboratory, 2014). Along with increased international trade, the production of goods and services has become multinational. This indicates the possibility of environmental pollution also being exported overseas.

In the context of globalization's remarkable rise, the relationship between trade and the environment has also been discussed in the literature. Among the debates on the impact of trade globalization on the environment, there are discussions on the pollution haven hypothesis (PHH) and carbon leakage terms (Cole, 2004; Dietzenbacher \& Mukhopadhyay, 2007; Gill et al., 2018; Mani \& Wheeler, 1998; Taylor, 2004; Wiebe \& Yamano, 2016).

Conventionally, the PHH and carbon leakage were terms related to environmental regulation and production activities. Relatively strict environment regulation in developed countries forced entrepreneurs to save energy and to introduce energy-saving technology, which raised the cost of the product when produced in developed countries. As a result, multinational companies tried to reduce costs by moving production bases to developing countries with lax environmental policies. Carbon leakage refers to the movement of carbon through the market mechanism. For instance, Copeland and Taylor (1994) considered the PHH in north-south trade under the North American Free Trade Agreement. Their research showed the connection between stringent environmental regulations and trade patterns in terms of a country's pollution. The research found that enterprises in highly 
regulated systems such as the United States or Canada were directly competitive with those operating in poorer countries with weak environmental standards like Mexico. In the globalization and liberalization era, developing countries could become PHHs for the pollution-intensive industries of advanced countries. Therefore, carbon leakage occurs because of the trade between developing countries and developed countries.

Yang (2001) tested the impacts on Taiwan's environment and $\mathrm{CO}_{2}$ emissions after Taiwan joined the World Trade Organization (WTO). The author applied computable general equilibrium (CGE) to see the interaction among the economic sectors and then employed the Laspeyres index to decompose the change in $\mathrm{CO}_{2}$ emissions after Taiwan joined the WTO in 1996. The results showed that, along with trade liberalization, $\mathrm{CO}_{2}$ emissions also increased. The net change in emissions was focused on some carbon-intensive sectors such as on-metallic mineral products, metal products, and electricity sectors. Yang's (2001) paper supported the PHH in Taiwan after it joined the WTO.

Dietzenbacher and Mukhopadhyay (2007) examined India's PHH. Their study estimated $\mathrm{CO}_{2}$ and $\mathrm{SO}_{2}$ emissions released into the environment when they assumed that exports and imports would increase by the same amount of 1 billion rupees. Although the authors expected that India would export pollution-intensive goods, they found the opposite results in the case of India. The amount of $\mathrm{CO}_{2}$ and $\mathrm{SO}_{2}$ emissions generated to produce one unit of exports were smaller than the pollution amounts avoiding being generated by one unit of imports. Consequently, India exports relatively clean goods and gains from the extra trade. This means that India was not a pollution haven in the 1990s.

Similar to Dietzenbacher and Mukhopadhyay (2007), Temurshoev (2011) employed the same methodology to examine the PHH or the factor endowment hypothesis for the United States and China for 1992 and 1997. This empirical research examined three cases of trade: (1) China's trade with the rest of the world; (2) U.S. trade with the rest of the world; and (3) the bilateral trade between China and the United States. It was revealed that a $\mathrm{PHH}$ does not exist in the case of bilateral trade and that China gained in terms of emissions. The author also found that, over time, the gains from trade with the United States are more beneficial in terms of $\mathrm{CO}_{2}$ emissions than the same increase in trade with the rest of the world.

Chen et al. (2011) found that China's export-oriented economy from 1993 to 2007 was good for the environment. Employing the simultaneous equation model, the authors investigated the interaction among economic growth, foreign trade, foreign direct investment (FDI), and the environment. The results of this research did not support the PHH. However, it could be interpreted that China was causing the rise of $\mathrm{CO}_{2}$ emissions in the rest of the world under its export-oriented economy.

On the other hand, in Jayanthakumaran and Liu's (2016) research, the result was the opposite for bilateral trade between China and Australia. Using 
the sector input-output (IO) model to calculate the $\mathrm{CO}_{2}$ emissions embodied in trade between China and Australia, the net $\mathrm{CO}_{2}$-embodied emissions transferred from Australia to China had a negative value. It can be shown that the Australian trade caused the rise of Chinese emissions in the period of 2008-2011. This research found that global $\mathrm{CO}_{2}$ emissions could increase by 39.13 million tons when Australia consumes China's export goods, but China's consumption of Australia's products could slow world emissions by 20.19 million $\mathrm{t}-\mathrm{CO}_{2}$. The authors suggested that the composition of more bilateral trade may help reduce global emissions.

Fan et al. (2019) also tested the $\mathrm{CO}_{2}$ embodied in Chinese trade in 2010 and 2011. The author created a panel data model to examine the impact of trade on $\mathrm{CO}_{2}$ emissions, using the single-region input-output (SRIO) model to decompose the industrial sector and carbon dioxide emissions. In general, the more open the trade, the more reduction in carbon intensity and gross emissions.

Carbon relocation is another environmental term. It occurs through FDI. Shahbaz et al. (2015) showed the change in emissions through FDI. The paper demonstrated the effects of FDI on the environments of low-, middle-, and high-income countries. The author used panel data from 1975 to 2012 and employed panel co-integration techniques. The results when economic growth gains $1 \%$, energy use and environmental pollution increase by $0.07 \%$ and $0.65 \%$, respectively. In turn, FDI decreases the $\mathrm{CO}_{2}$ emissions in high-income countries in every period, but this does not happen in lowincome countries. In low-income countries, FDI speeds environmental degradation. The result supports the $\mathrm{PHH}$. Carbon leakage is the movement of carbon through the market mechanism, but carbon relocation refers to the redirection of carbon according to policies of carbon-intensive countries like China. There is a significant difference between carbon leakage and carbon relocation. However, carbon leakage and carbon relocation cannot be distinguished in terms of phenomena.

After specifying the differences in carbon leakage and carbon relocation definitions, this chapter aimed to estimate the international carbon leakage that considers the differences in technology levels of imported goods and services between countries. Previous studies used the SRIO table (Dietzenbacher and Mukhopadhyay, 2007; Temurshoev, 2011) assuming the technology levels of imported goods and services same between the home countries and the rest of the world due to unavailability of international intermediate trade data. The results calculated by such an SRIO approach disregarded the $\mathrm{CO}_{2}$ emissions from importing goods and services and thus may underestimate the international carbon leakage. As a supplementation, we used the multi-region input-output (MRIO) approach in addition to the SRIO so that technology levels of both domestic and importing countries can be included for the carbon leakage examination.

This chapter also focuses on the emissions induced by international trade. It examines whether China has been transferring $\mathrm{CO}_{2}$ emissions to 
Asian countries through bilateral trade or receiving overseas $\mathrm{CO}_{2}$ emissions. Further, the chapter investigates whether the pattern of China's bilateral emissions transfer has changed from 2005 to 2015. We selected four trade partner countries in Asia to use when considering the range of economic development level, specifically by the indicator GDP per capita (China US $\$ 4,550$ in 2010). These countries include Vietnam (US $\$ 1,318$ ), India (US $\$ 1,358$ ), and Indonesia (US $\$ 3,122$ ) with GDP per capita smaller than China, as well as Japan (US \$44,508, GDP per capita in 2010, World Bank, 2011), larger than China. This chapter contributes to a better understanding of the role of one country in the global carbon transaction. It examined different carbon leakage hypnosis by the application of two examination approaches: SRIO and MRIO analyses. The latter one distinguishes emission intensities of imports and domestic production, which is a feature of international trade that has not received enough attention in the previous literature.

\section{Methodology}

This chapter adopts input-output methodology to calculate embodied emissions and to further examine whether China has been transferring $\mathrm{CO}_{2}$ emissions to Asian countries through bilateral trade or has been receiving overseas $\mathrm{CO}_{2}$ emissions. The literature has applied various methodologies to evaluate the interaction between global business and the environment, such as CGE (Yang, 2001) and econometric models (Chen et al., 2011). However, use of the econometric models may involve the endogeneity of explanatory variables. In addition, the model may test for only a single country and may lack data for developing countries. One of the advantages of input-output (IO) analysis is that it does not depend on the availability of long-term series data to track emissions. Moreover, it can also distinguish the demand for various fuel types in economic sectors that show the interrelation of production sectors in the economy. Computer generated equilibrium models can also become the extension of IO models. However, the disadvantage of CGE is the complexity of their computation and the validation difficulty. Therefore, the IO approach can be considered as appropriate.

We further applied both the SRIO and MRIO approaches to cover the importance of intermediate goods and services in this chapter.

\subsection{The structure of the single-region input-output table}

The structure of an SRIO table is shown in Figure 11.1. The vector $\mathbf{x}_{r}$ represents the total input (output) for all sectors in region $r$. The matrix $\mathbf{A}_{r} \widehat{\mathbf{x}_{r}}$ displays the flow between domestic sources (rows) and domestic destinations (columns) by sectors in region $r$ and the import intermediate demand. The 


\begin{tabular}{|c|c|c|c|}
\hline & $\begin{array}{c}\text { Intermediate } \\
\text { demand }\end{array}$ & $\begin{array}{c}\text { Final } \\
\text { demand }\end{array}$ & $\begin{array}{c}\text { Total } \\
\text { output }\end{array}$ \\
\hline $\begin{array}{c}\text { Intermediate } \\
\text { input }\end{array}$ & $\mathbf{A}_{\mathrm{r}} \widehat{\mathbf{x}}_{\mathbf{r}}$ & $\mathbf{y}_{\mathrm{r}}$ & \multirow{2}{*}{$\mathbf{x}_{\mathbf{r}}$} \\
\hline Value added & $\mathbf{v}_{\mathbf{r}}$ & \multicolumn{2}{|}{} \\
\hline Total input & $\mathbf{x}_{\mathbf{r}}^{\prime}$ & \multicolumn{2}{|l}{} \\
\cline { 1 - 2 }
\end{tabular}

Figure 11.1 Structure of a single-region input-output table in region $r$. Source: Authors.

matrix $\mathbf{y}_{r}$ represents the final demand for goods and services in region $r$. The matrix $\mathbf{V}_{r}$ represents the value added in region $r$.

\subsection{The structure of the multiple-region input-output table}

The structure of an MRIO table is shown in Figure 11.2. Compared with that of the SRIO table, the total input (output) for all sectors is expanded to all $k$ regions; e.g., $\mathbf{x}_{k}$ represents the total input (output) for all sectors in region $k$.

The intermediate demand matrix is expanded to all $k$ regions; e.g., $\mathbf{A}_{\boldsymbol{k} 2} \widehat{\mathbf{x}_{\boldsymbol{k}}}$ represents the input of intermediate goods and services for all sectors from region $k$ to region 2. Similarly, the final demand matrix and the value-added matrix are also expanded to all $k$ regions; e.g., $\mathbf{y}_{\boldsymbol{k} 2}$ represents the input of final products and services for all sectors from region $k$ to region 2 , and $\mathbf{v}_{k}$ represents the value added in region $k$.

\subsection{Analysis by a single-region approach}

The emission coefficient of the $i$ th sector in the $r$ th region, $c_{i r}$, is formulated in Equation 11-1.

$$
c_{i r}=p_{i r} / x_{i r}(i=1, \cdots, n ; r=1, \cdots, k),
$$

where $p_{i r}$ represents the direct $\mathrm{CO}_{2}$ emissions of sector $i$; $x_{i}$ represents the total output of sector $i ; c_{i r}$ is one of the elements of the direct-emission coefficient vector $\mathbf{c}_{r}$ for all $n$ sectors in region $r$; and $\mathbf{c}_{r}$ is also one of the elements of the direct-emission coefficient vector $\mathbf{c}$ for all $n$ sectors in all $k$ regions.

The total output $\mathbf{x}_{\mathbf{r}}$ of all $n$ sectors in region $r$ meets the production balance in Equation 11-2.

$$
\mathbf{x}_{r}=\left[\mathbf{I}-\mathbf{A}_{r}\right]^{-1} \mathbf{y}_{\boldsymbol{r}}
$$




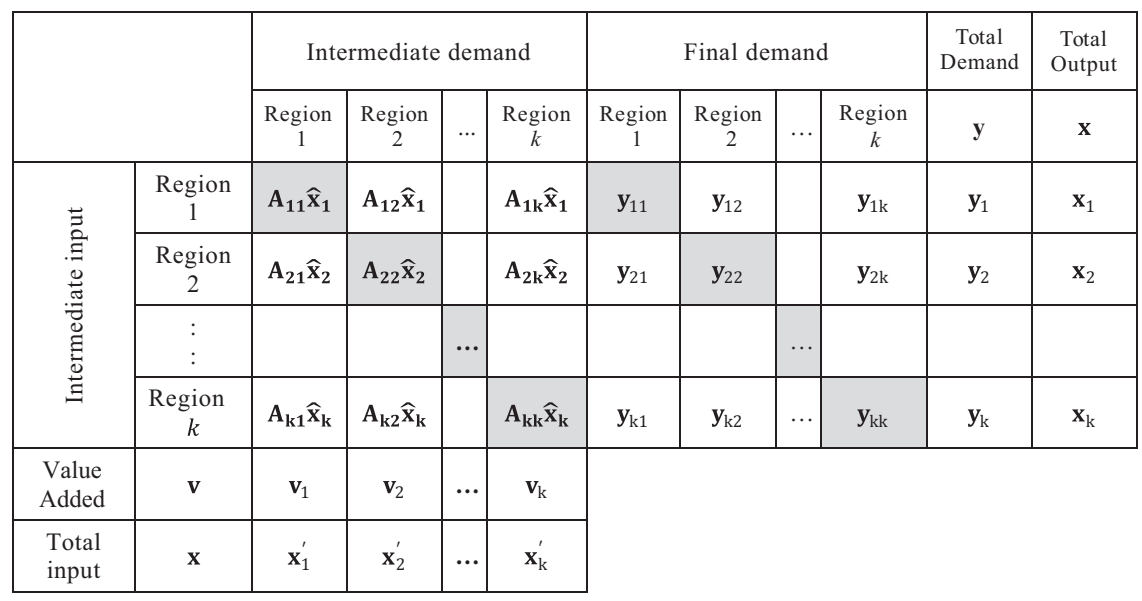

Figure 11.2 Structure of a multi-region input-output table.

Source: Authors.

where $\mathbf{A}_{\boldsymbol{r}}$ represents the $n \times n$ intermediate input coefficient matrix of region $r$ and $\mathbf{y}_{\boldsymbol{r}}$ represents the final demand of region $r$. The final demand consists of household (and non-profit institutions serving households) final consumption, final government consumption, gross fixed-capital formation, changes in inventories, and the acquisitions less disposals of valuables.

Total $\mathrm{CO}_{2}$ emissions induced by the export from region $r$ to region $s, \mathbf{c t}_{r \boldsymbol{s}}$, are formulated as

$$
\mathbf{c t}_{r s}=\widehat{\mathbf{c}_{r}}\left[\mathbf{I}-\mathbf{A}_{r}\right]^{-1} \mathbf{y}_{r s}(r=1, \cdots, k ; s=1, \cdots, k),
$$

where the direct-emission coefficient vector in the $r$ th region $\mathbf{c}_{\boldsymbol{r}}$ is diagonalized; $\mathbf{y}_{r s}$ represents the goods and services exported from region $r$ to region $s$, and both intermediate and final exports are included. Total $\mathrm{CO}_{2}$ emissions induced by the imported goods of region $r$ from region $s$ can be calculated in Equation 11-4, which is similar to that of Dietzenbacher and Mukhopadhyay (2007):

$$
\mathbf{c t}_{s r}=\widehat{\mathbf{c}_{\boldsymbol{r}}}\left[\mathbf{I}-\mathbf{A}_{\boldsymbol{r}}\right]^{-1} \mathbf{y}_{\boldsymbol{s} r}(r=1, \cdots, k ; s=1, \cdots, k),
$$

where $\mathbf{y}_{\boldsymbol{s}}$ represents the export of final demands from region $s$ to region $r$. However, in this equation, the direct-emission coefficient vector in the $r$ th region $\mathbf{c}_{\boldsymbol{r}}$ is utilized, which means Dietzenbacher and Mukhopadhyay (2007) assumed that imported goods from the rest of the world have the 
same technology as that of region $r$. Thus, the result indicates that the total $\mathrm{CO}_{2}$ is avoided in region $r$ through its imports. This estimation approach is limited by the data access at the time and may lead to large uncertainties in results. This can be improved with Equation 11-5, where total $\mathrm{CO}_{2}$ emissions induced by importing from region $s$ to region $r$ can also be calculated by

$$
\mathbf{c t}_{\boldsymbol{s} \boldsymbol{r}}^{*}=\widehat{\mathbf{c}_{\boldsymbol{s}}}\left[\mathbf{I}-\mathbf{A}_{\boldsymbol{s}}\right]^{-1} \mathbf{y}_{s r}(r=1, \cdots, k ; s=1, \cdots, k),
$$

where the direct-emission coefficient vector in region $s, \mathbf{c}_{\boldsymbol{s}}$, is utilized.

In this chapter, both intensity vectors, namely, the vector of the receiving regions of the imported goods (used in $\mathbf{c t}_{s r}$ ) and the vector of the original regions of the imported goods (used in $\mathbf{c t}_{s r}^{*}$ ), were examined.

The trade balance of total $\mathrm{CO}_{2}$ emissions, $t b_{r s}$, if

$$
t b_{r s}=\mathbf{l}\left[\mathbf{c t}_{r s}-\mathbf{c t}_{\boldsymbol{s} r}\right]<0(r=1, \cdots, k ; s=1, \cdots, k),
$$

region $r$ caused the rise of emissions in region $s$. Also, if

$$
t b_{r s}=\mathfrak{\imath}\left[\mathbf{c t}_{r s}-\mathbf{c t}_{s r}^{*}\right]<0(r=1, \cdots, k ; s=1, \cdots, k),
$$

region $r$ avoided domestic $\mathrm{CO}_{2}$ emissions by the imports from region $s$. In other words, region $r$ caused the rise of emissions in region $s$.

However, in a one-country IO table, it is not possible to obtain the directemission coefficient vector $\mathbf{c}_{\boldsymbol{s}}$ and matrix $\mathbf{A}_{\boldsymbol{s}}$. Therefore, the second examination can be improved with a multi-region approach, as shown in the next section.

\subsection{Analysis through a multi-region approach}

The total output of all $n$ sectors in all $k$ regions, $\mathbf{x}$, meets the production balance in Equation 11-8:

$$
\left[\begin{array}{c}
\mathbf{x}_{1} \\
\vdots \\
\mathbf{x}_{k}
\end{array}\right]=\left[\mathbf{I}-\left[\begin{array}{ccc}
\mathbf{A}_{11} & \cdots & \mathbf{A}_{1 k} \\
\vdots & \ddots & \vdots \\
\mathbf{A}_{k 1} & \cdots & \mathbf{A}_{k k}
\end{array}\right]\right]^{-1}\left[\begin{array}{c}
\mathbf{y}_{11}+\cdots+\mathbf{y}_{1 k} \\
\vdots \\
\mathbf{y}_{k 1}+\cdots+\mathbf{y}_{k k}
\end{array}\right]
$$

where $\mathbf{A}_{r s}$ represents the $n \times n$ intermediate coefficient matrix of region $r$ 's imports from region $s$. The final demands for goods and services are separated by country and sector in $\mathbf{y}$ (e.g., $\mathbf{y}_{1 k}$ represents the $n \times 1$ vector of final goods and services from region 1 to region $k$ ). 
The total $\mathrm{CO}_{2}$ trade emissions in all $n$ sectors in all $k$ regions, $\boldsymbol{C}^{\boldsymbol{t}}$, can be formulated as

$$
\boldsymbol{C}^{t}=\hat{\mathbf{c}}\left[\mathbf{I}-\left[\begin{array}{ccc}
\mathbf{A}_{11} & \cdots & \mathbf{A}_{1 \boldsymbol{k}} \\
\vdots & \ddots & \vdots \\
\mathbf{A}_{k 1} & \cdots & \mathbf{A}_{k \boldsymbol{k}}
\end{array}\right]\right]^{-1}\left[\begin{array}{ccc}
\widehat{\mathbf{y}_{11}} & \cdots & \widehat{\mathbf{y}_{1 k}} \\
\vdots & \ddots & \vdots \\
\widehat{\mathbf{y}_{k 1}} & \cdots & \widehat{\mathbf{y}_{\boldsymbol{k} k}}
\end{array}\right],
$$

where the direct-emission coefficient vector of all $k$ regions $\mathbf{c}$ is diagonalized.

The total $\mathrm{CO}_{2}$ trade emissions between regions $r$ and $s, \mathbf{C}^{t}$, can be considered as

$$
\mathbf{C}^{t}=\left[\begin{array}{ccc}
\mathbf{C}_{11}^{t} & \cdots & \mathbf{C}_{1 k}^{t} \\
\vdots & \ddots & \vdots \\
\mathbf{C}_{k 1}^{t} & \cdots & \mathbf{C}_{k k}^{t}
\end{array}\right]
$$

The trade balance of total $\mathrm{CO}_{2}$ emissions from region $r$ to region $s, t b_{r s}$ is:

$$
t b_{r s}={ }\left[\mathbf{C}_{r s}^{t}-\mathbf{C}_{s r}^{t}\right]^{\prime}<0(r=1, \cdots, k ; s=1, \cdots, k),
$$

If $t b_{r s}<0$, region $r$ caused the rise of emissions in region $s$.

In this chapter, the $k$ regions include Vietnam, Indonesia, India, Japan, and the rest of the world. All $26 n$ sectors include agriculture, mining and quarrying, and electrical and machinery, as shown in Table 11 Appendix, Sectors.

\subsection{Data sources}

This chapter employs the IO tables from the Eora Global Supply Chain Database (EORA database) for the years 2005, 2010, and 2015 with the basic prices. The EORA database is the global supply chain database that provides the time series IO tables for 190 countries with environmental satellite accounts. Currently, this database has three formats: the individual country IO tables, EORA26, and full EORA. EORA26 will be employed in this chapter because all industries were aggregated into 26 sectors. With the different numbers of industries or commodities among 190 countries, using EORA26 will be more suitable and easier to analyze and compare among country sectors.

The EORA database also offers both basic and purchase prices. However, in this research, the basic price will be used because it has already deducted the tax payable and has included the subsidy for one unit of goods and services output. This keeps the transaction value between producers and consumers as homogenous as possible. In terms of sector-level emissions, the 
study also includes the $\mathrm{CO}_{2}$ emissions from EORA26 for the years 2005, 2010, and 2015.

Three data providers were used to create the $\mathrm{CO}_{2}$ and greenhouse gas satellite account rows in the EORA database: the Emission Database for Global Atmospheric Research (EDGAR), the Carbon Dioxide Information Analysis Center (CDIAC), and the PRIMAPHIST model. However, this chapter used the Potsdam Real-time Integrated Model for the Probabilistic Assessment of Emission Paths (PRIMAP) to obtain the total $\mathrm{CO}_{2}$ generated by sectors in all countries because it included the EDGAR and CDIAC data.

\section{Results}

\subsection{National $\mathrm{CO}_{2}$ emissions during 2005-2015}

Figure 11.3 represents the total national $\mathrm{CO}_{2}$ emissions of China and selected Asian countries from 2005 to 2015 based on the EORA database. In general, China is the highest $\mathrm{CO}_{2}$ emitter among the six countries. China's carbon emissions increased from 6.2 billion t- $\mathrm{CO}_{2}$ in 2005 to 10.8 billion t- $\mathrm{CO}_{2}$ in the period from 2005 to 2015. National $\mathrm{CO}_{2}$ emissions in Vietnam and India are relatively insignificant compared with China's; however, they increased significantly from 2005 to 2015. Vietnam's $\mathrm{CO}_{2}$ doubled from 99 million t- $\mathrm{CO}_{2}$ in 2005 to 203 million t- $\mathrm{CO}_{2}$ in 2015. Similarly, India's emissions increased from 1.2 to 2.3 billion t- $\mathrm{CO}_{2}$ in the same period. Emissions in Indonesia also increased by 36\% from 2005 to 2015. The only decrease in total national $\mathrm{CO}_{2}$ occurred in Japan, which had a $4 \%$ drop over ten years.

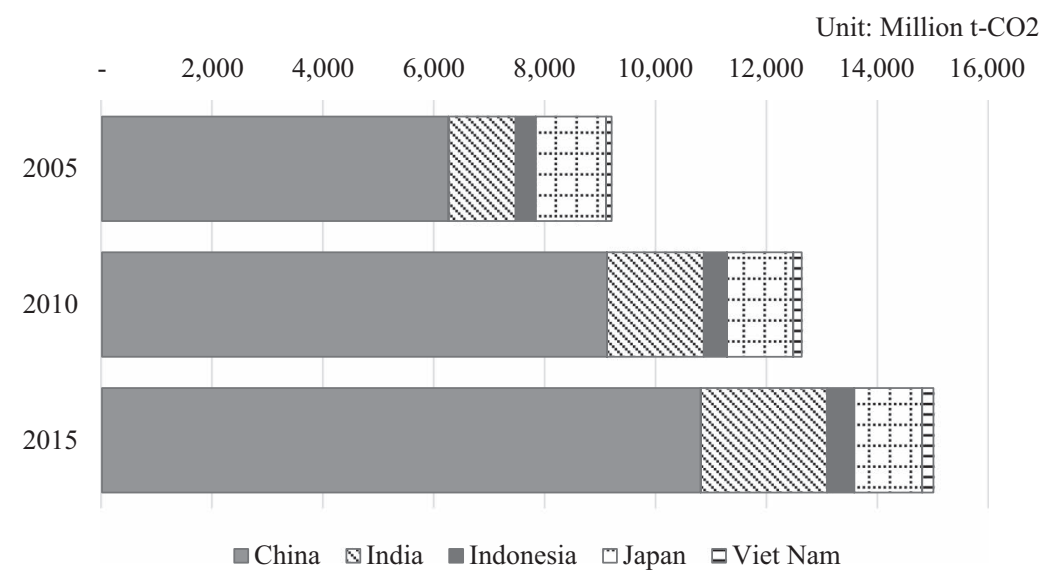

Figure 11.3 Total national $\mathrm{CO}_{2}$ emissions, 2005-2015.

Source: EORA database. 
Table 11.1 Direct-emission coefficients of main industrial sectors in selected Asian countries (Unit: million t- $\mathrm{CO}_{2} / \mathrm{US} \$$ billion)

\begin{tabular}{|c|c|c|c|c|c|c|c|c|c|c|}
\hline & \multicolumn{5}{|l|}{2005} & \multicolumn{5}{|l|}{2015} \\
\hline & $C H N$ & $I D N$ & $I N D$ & $J P N$ & $V N M$ & $C H N$ & $I D N$ & $I N D$ & $J P N$ & $V N M$ \\
\hline Agriculture & 0.81 & 1.03 & 1.20 & 0.16 & 1.06 & 0.58 & 0.59 & 1.00 & 0.12 & 0.82 \\
\hline Fishing & 0.77 & 0.84 & 0.83 & 0.15 & 0.97 & 0.58 & 0.55 & 0.95 & 0.10 & 0.47 \\
\hline Mining & 1.35 & 1.12 & 2.22 & 0.18 & 2.49 & 0.63 & 0.70 & 1.40 & 0.08 & 2.66 \\
\hline Food & 0.44 & 0.40 & 0.75 & 0.20 & 0.57 & 0.22 & 0.24 & 0.72 & 0.16 & 0.48 \\
\hline Textiles & 0.71 & 0.41 & 0.79 & 0.25 & 1.38 & 0.40 & 0.29 & 0.75 & 0.23 & 1.75 \\
\hline Pet. \& Chemical & 1.07 & 1.61 & 1.03 & 0.17 & 0.67 & 0.48 & 0.60 & 0.73 & 0.10 & 0.45 \\
\hline Metal & 0.99 & 1.44 & 0.99 & 0.15 & 1.31 & 0.32 & 0.49 & 0.56 & 0.08 & 0.58 \\
\hline Machinery & 0.93 & 1.35 & 0.87 & 0.18 & 1.19 & 0.39 & 0.61 & 0.58 & 0.14 & 0.62 \\
\hline Transport Equipment & 0.20 & 0.09 & 0.12 & 0.07 & 0.37 & 0.13 & 0.04 & 0.09 & 0.05 & 0.15 \\
\hline Other Manufacturing & 0.91 & 0.86 & 0.90 & 0.18 & 1.51 & 0.52 & 0.47 & 0.65 & 0.14 & 0.71 \\
\hline Electricity & 17.01 & 18.27 & 16.11 & 5.13 & 32.12 & 6.28 & 11.60 & 14.18 & 3.50 & 34.54 \\
\hline
\end{tabular}

Source: The authors' calculations are based on the EORA database.

The direct-emission coefficients of the main sectors are shown in Table 11.1. The results were divided into the non-electricity sectors and the electricity sector from 2005 to 2015 . Generally, the direct-emission coefficient slowed from 2005 to 2015. However, there are some differences in outcomes among these countries. Among the main sectors, the electricity sector has the highest emission coefficient, followed by the mining sector. Japan had a low direct-emission coefficient in both the electricity sector and the non-electricity sectors. In contrast, China, Vietnam, India, and Indonesia have a relatively large volume of emissions per monetary unit. However, China and India decreased their emission coefficients by year and by sector, but Vietnam tended to enhance its emission coefficients from 2005 to 2015, especially in the mining sector.

The emission coefficient expresses the volume of emissions per unit of GDP, the reduction of which can be interpreted as less pollution released per unit of GDP. Countries with small emission coefficients may have better technology or more efficient energy consumption than those with high coefficients.

\subsection{Bilateral CO2 trade during 2005-2015}

Table 11.2 shows the trade balance and corresponding embodied emissions between China and the selected Asian countries. The results are listed using both the SRIO and MRIO approaches.

According to the IO table, China was the net exporter of final demands to Vietnam, India, Indonesia, and Japan in both selected years. Following a similar pattern, the emissions that China transferred to Vietnam, India, Indonesia, and Japan through the export of final demands also overweighed 
Table 11.2 China's bilateral trade with selected Asian countries and the corresponding embodied emissions using the single-region I-O (SRIO) and multi-region I-O (MRIO) approach

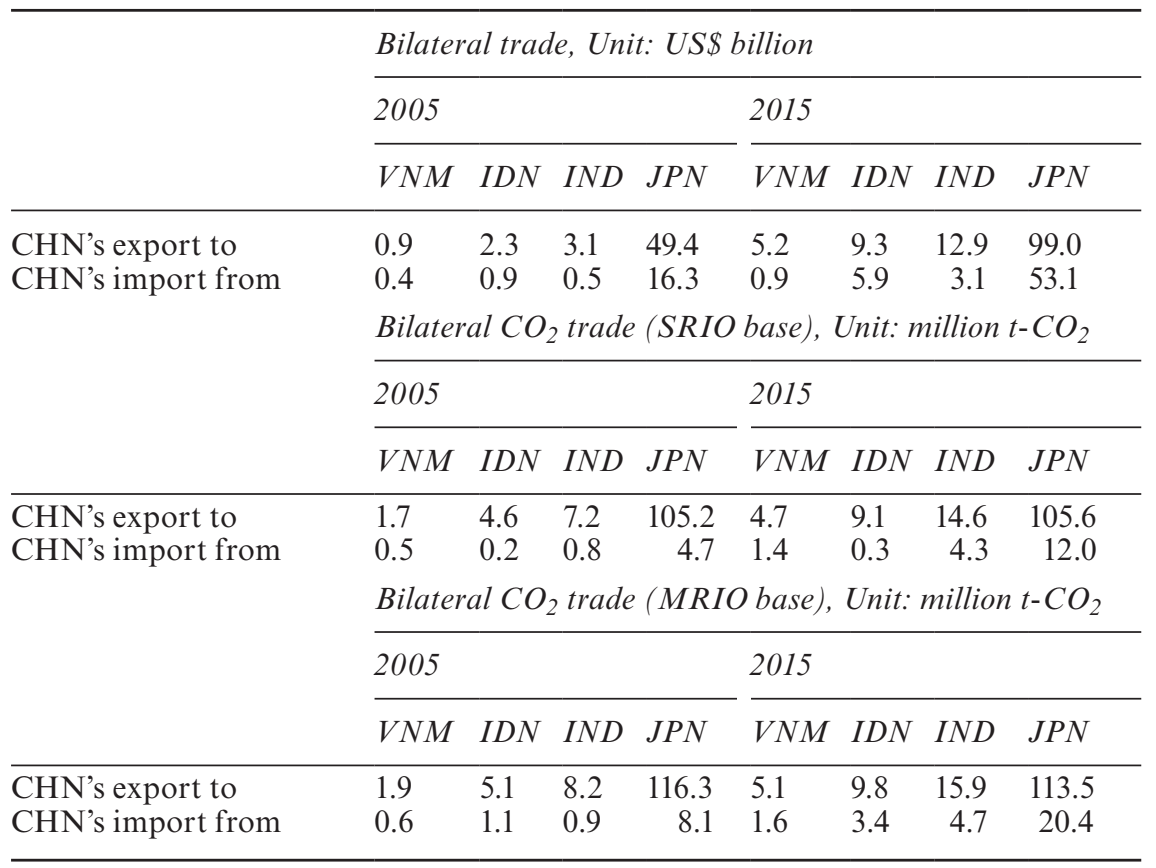

Source: The authors' calculations are based on the EORA database.

those that arrived through imported goods. The gaps between the bilateral emission export and import between China and Japan (105.6 vs. 12.0 million $\mathrm{t}-\mathrm{CO}_{2}$ by the SRIO approach or 113.5 vs. 20.4 million $\mathrm{t}-\mathrm{CO}_{2}$ by the MRIO approach) were far larger than the gaps between the bilateral export and import (US\$99.0 billion vs. US\$53.1 billion). China has been exporting more "dirty goods" (pollution-intensive goods) to Japan.

Comparing the results in 2005 and 2015, the emissions that China transferred to Vietnam, India, and Indonesia largely increased (by $176.5 \%$, $97.8 \%$, and $102.8 \%$, respectively, using the SRIO approach). The bilateral emissions exported from China to Japan over those ten years remained nearly the same. On the other hand, the emissions that China imported from Vietnam, India, and Japan largely increased (by $180.0 \%, 437.5 \%$, and $155.3 \%$, respectively, using the SRIO approach). The increase in bilateral emissions imported from Indonesia to China during those ten years was slight.

When the results of the SRIO and MRIO approaches are compared, the bilateral emission trade results calculated by the MRIO approach are larger than the results calculated by the SRIO approach. All indirect emissions, namely, the emissions generated in the domestic production activities in all 
sectors, are considered. Moreover, under the SRIO approach, the emissions that China transferred to Japan slightly increased from 105.2 to 105.6 million $\mathrm{t}-\mathrm{CO}_{2}$; however, under the MRIO approach, such an increase turned into a slight decrease from 116.3 to 113.5 million t- $\mathrm{CO}_{2}$. The SRIO approach, without considering intermediate imports and indirect domestic emissions, underestimated such growth. This can only be revealed by conducting the MRIO approach.

The difference in total net bilateral $\mathrm{CO}_{2}$ trade results based on the singleregion and multi-region approaches is shown in Figure 11.4.

Under both approaches, China was net exporting $\mathrm{CO}_{2}$ induced by final demand exports to all selected countries in both 2005 and 2015, especially to Japan. Japan has been causing the rise in emissions in China. However, the number has decreased from 2005 to 2015 ( -6.9 million t- $\mathrm{CO}_{2}$ by the SRIO approach and -7.4 million t- $\mathrm{CO}_{2}$ by the MRIO approach). The rise in emissions in China caused by Japan has slowed. On the other hand, according to the results of this chapter, China has not been causing the emission rises in Vietnam, India, or Indonesia.

Emissions embodied per unit of export from China decreased from 2005 to 2015 with all the selected countries, as shown in Table 11.3. This indicates that more low-emission technologies have been adopted in the production activities in China over ten years. In 2005, in all selected bilateral trade partners, the emissions embodied per unit of exports from China were larger than the emissions embodied per unit of imports from Vietnam (1.8 vs. 1.3

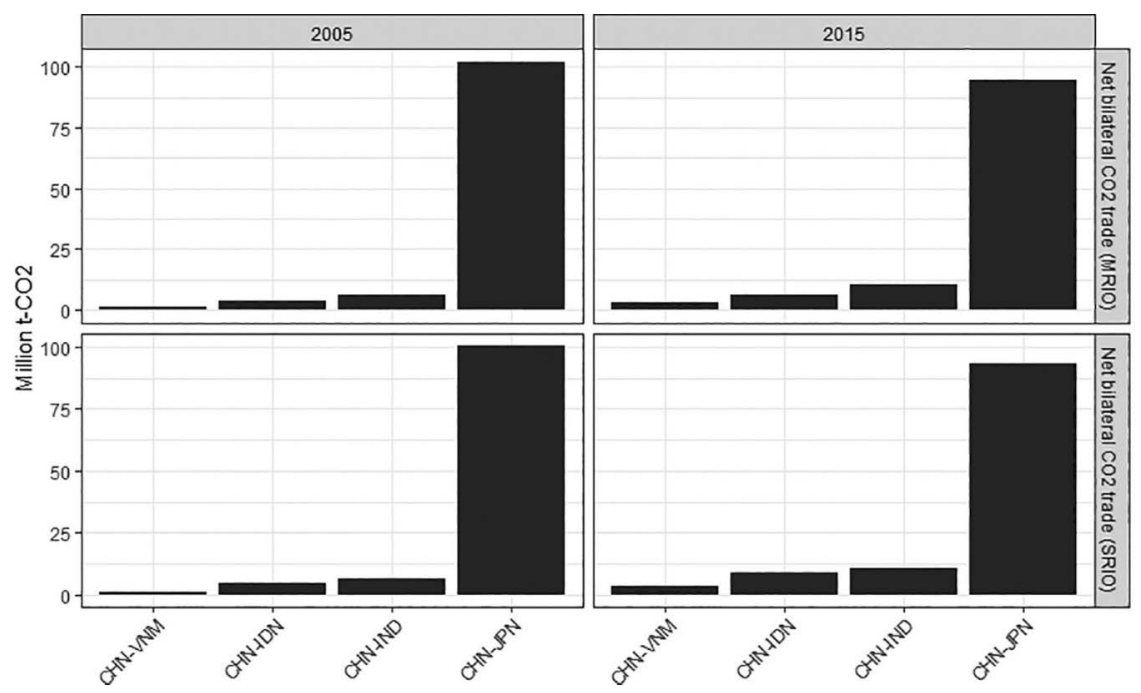

Figure 11.4 Total net bilateral emissions trade of China with selected Asian countries using the single-region input-output (SRIO) and multi-region input-output (MRIO) approaches.

Source: The authors' calculations based on the EORA database. 
Table 11.3 Emissions embodied per unit of bilateral trade

\begin{tabular}{|c|c|c|c|c|c|c|c|c|}
\hline & \multicolumn{8}{|c|}{$\begin{array}{l}\text { Emissions embodied per unit of bilateral trade, Unit: million } \\
t-\mathrm{CO}_{2} / U S \$ \text { billion, Unit: million } \mathrm{t}-\mathrm{CO}_{2} / U S \$ \text { billion }\end{array}$} \\
\hline & \multicolumn{4}{|l|}{2005} & \multicolumn{4}{|l|}{2015} \\
\hline & $V N M$ & $I D N$ & $I N D$ & $J P N$ & $V N M$ & $I D N$ & $I N D$ & $J P N$ \\
\hline CHN's export to & 1.8 & 2.0 & 2.4 & 2.2 & 0.9 & 1.0 & 1.1 & 1.1 \\
\hline CHN's import from & 1.3 & 1.0 & 1.6 & 0.3 & 1.4 & 0.5 & 1.4 & 0.2 \\
\hline
\end{tabular}

Source: The authors' calculations based on the EORA database.

million t- $\mathrm{CO}_{2} / \mathrm{US} \$$ billion) and India (2.4 vs. 1.6 million $\mathrm{t}-\mathrm{CO}_{2} / \mathrm{US} \$$ billion). However, in 2015, the balance has reversed. The emissions embodied per unit of exports from China became smaller than the emissions embodied per unit of imports from Vietnam ( 0.9 vs. 1.4 million $\mathrm{t}-\mathrm{CO}_{2} / \mathrm{US} \$$ billion) and India (1.1 vs. 1.4 million $\mathrm{t}-\mathrm{CO}_{2} / \mathrm{US} \$$ billion). The structure of bilateral export from China to these countries has been switched to a smaller weight of pollution-intensive goods and services. If the China-Vietnam or ChinaIndia trade balance keeps growing according to this trend, China will cause emissions to rise in these countries. Moreover, on the import side, in all selected bilateral trade partners, the emissions embodied per unit of China's imports increased in the case of Vietnam. Vietnam was exporting more pollution-intensive goods and services to China from 2005 to 2015.

\subsection{Bilateral CO2 trade at the sector level}

The changes from 2005 to 2015 in bilateral $\mathrm{CO}_{2}$ emissions based on the single-region and multi-region approaches are decomposed into sectors in this section. Figures 11.5-11.7 show the changes in the net trade balance of total emissions in the China-Vietnam, China-Indonesia, China-India, and China-Japan trade, respectively. There are three representative cases that show the diversity in the change patterns of net $\mathrm{CO}_{2}$-embodied emissions. Because the net $\mathrm{CO}_{2}$ emissions transferred from China to other countries were all positive, it can be interpreted that bilateral trade partners have caused the increase of $\mathrm{CO}_{2}$ emissions in China. However, the trendsnamely, the changes in net bilateral emissions from 2005 to 2015-follow different patterns.

Under both approaches, Figure 11.5 shows that China's net bilateral $\mathrm{CO}_{2}$ export with Vietnam has largely grown from 2005 to 2015, especially in electricity supply, petrochemical products, and machinery sectors. The SRIO approach cannot cover the indirect emissions embodied in the domestic production activities induced by international trade, and therefore, such growth was underestimated compared with that under the MRIO approach. 

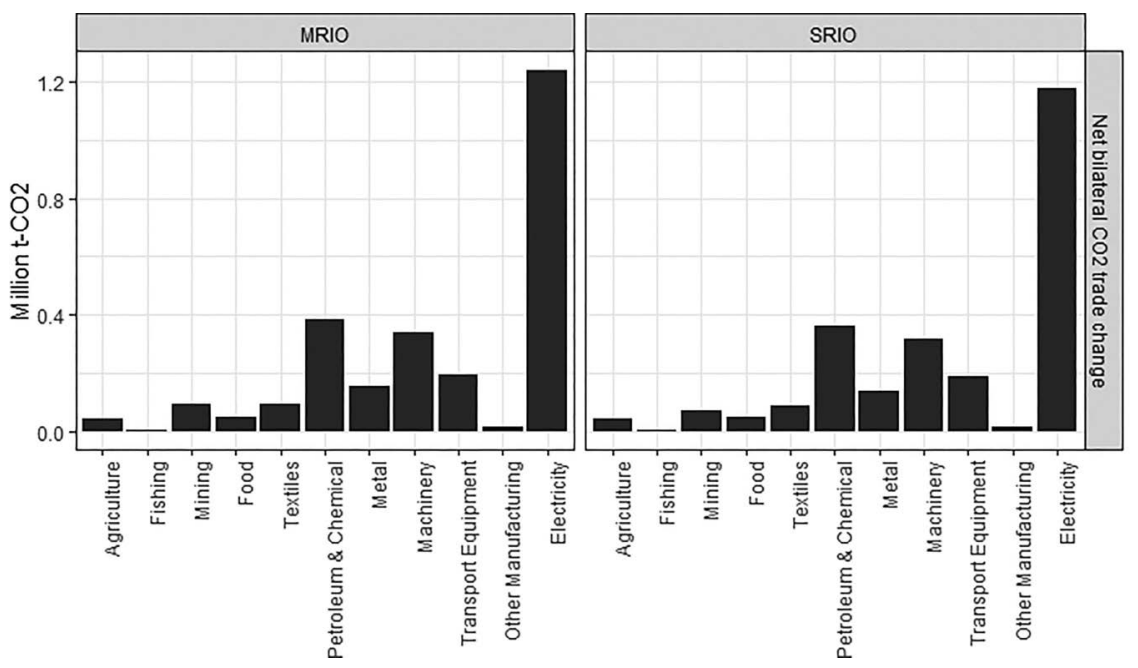

Figure 11.5 Changes from 2005 to 2015 in China's net bilateral $\mathrm{CO}_{2}$ export with Vietnam at the sector level using the single-region input-output (SRIO) and multi-region input-output (MRIO) approaches.

Source: The authors' calculations based on the EORA database.
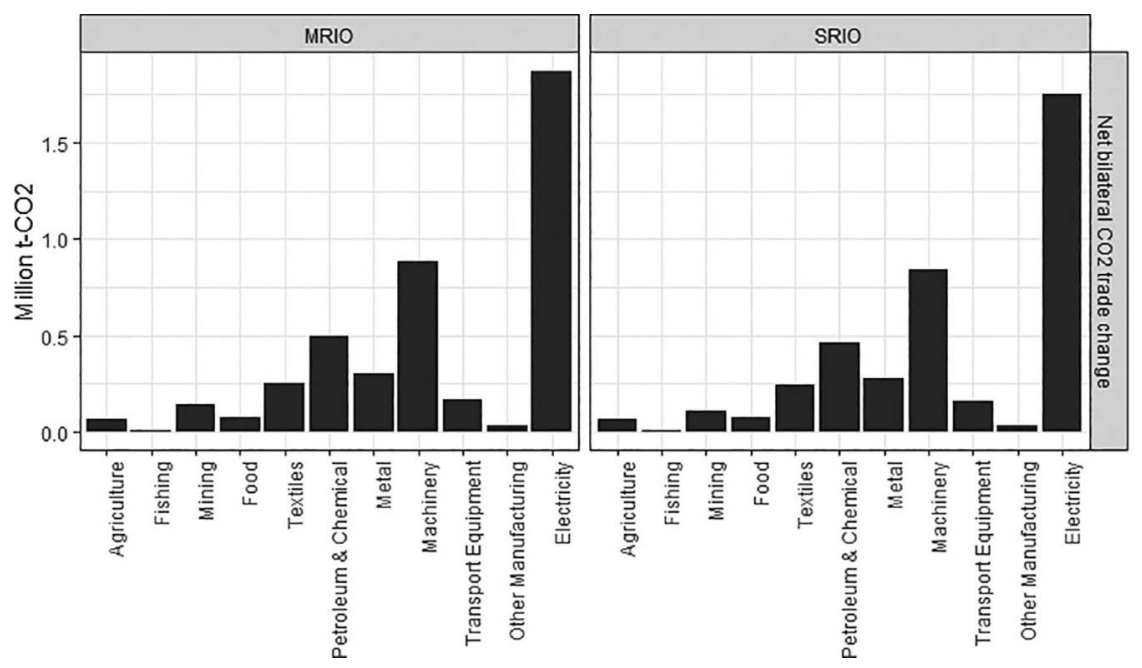

Figure 11.6 Changes from 2005 to 2015 in China's net bilateral $\mathrm{CO}_{2}$ export with Indonesia at the sector level using the single-region input-output (SRIO) and multi-region input-output (MRIO) approaches.

Source: The authors' calculations based on the EORA database. 


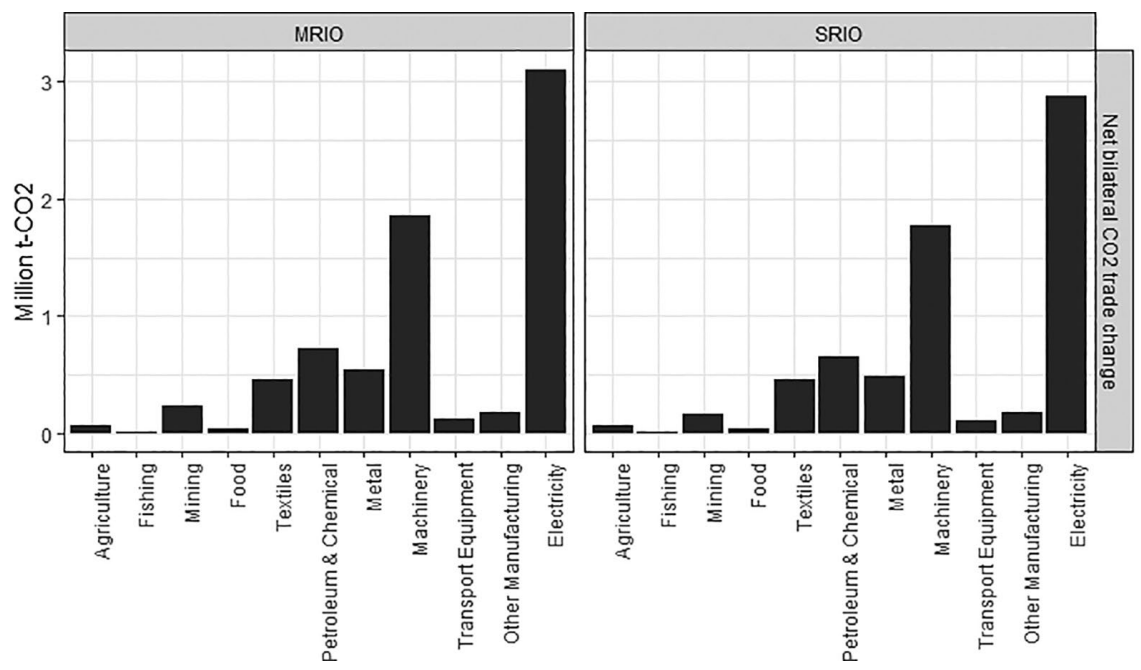

Figure 11.7 Changes from 2005 to 2015 in China's net bilateral $\mathrm{CO}_{2}$ export with India at the sector level using the single-region input-output (SRIO) and multi-region input-output (MRIO) approaches.

Source: The authors' calculations are based on the EORA database.

In Figure 11.6 (China-Indonesia) and Figure 11.7 (China-India), similar to the China-Vietnam case, China's net bilateral $\mathrm{CO}_{2}$ export has largely grown from 2005 to 2015 . The top three sectors were the electricity supply sector, the machinery sector, and petrochemical products sector under both approaches.

In contrast to the cases for Vietnam, Indonesia, and India, China's net bilateral $\mathrm{CO}_{2}$ export with Japan shrank in most sectors from 2005 to 2015, especially in the electricity supply, petrochemical products, and transportation equipment sectors. The net bilateral $\mathrm{CO}_{2}$ trade increased in the textiles and other manufacturing sectors.

\section{Discussion}

In the bilateral $\mathrm{CO}_{2}$ trade, China has been net exporting $\mathrm{CO}_{2}$ through final demand exports (Figure 11.5, 11.6, and 11.7). Emissions embodied per unit of export from China decreased from 2005 to 2015 with all selected countries, indicating an improvement at the low-emission technology level in domestic production in China. However, the emissions embodied per unit of China's imports increased in the case of Vietnam. This implies that 
emission-intensive goods and services exported from Vietnam to China have increased during 2005-2015.

Such an increase can be related to changes in both the amount of bilateral trade (scale factor) and emission intensity (intensity factor). First, the exports of intermediate and final goods have significantly increased in many sectors, while the structure of bilateral export, especially the top five sectors were relatively stable from 2005 to 2015 (Table 11.4). In particular, mining, the largest export sector, increased from 1.71 to 3.82 US\$ billion. Second, the change in the emission intensity varies by sector. While the agriculture and the food sector actually became less emission-intensive 2005-2015, the textile sector largely increased from 1.38 to 1.75 million $\mathrm{t}-\mathrm{CO}_{2} / \mathrm{US} \$$ billion. This can be related to the large increase in the intermediate input of electricity in the textile sector (third largest sector in 2015 with an input coefficient of 0.0326 , shown in Table 11.4). The electricity supply sector was exactly the most emission-intensive sector in Vietnam, and the most emission-intensive sector in all countries discussed in this chapter. According to Chapter 2 in this book, the energy mix in power generation in Vietnam from 2005 to

Table 11.4 2005-2015 changes in Vietnam: input coefficients from the electricity supply sector and exports from Vietnam to China

2005

Direct-emission intensity of the electricity supply sector in Vietnam (million $\mathrm{t}-\mathrm{CO}_{2} / \mathrm{US} \$$ billion)

Input coefficients from the electricity supply sector (top 5 of all sectors) in Vietnam

$\begin{array}{llll}\text { Top 5 sectors } & \text { Value } & \text { Top 5 sectors } & \text { Value } \\ \text { Mining } & 0.0457 & \text { Petroleum \& Chemical } & 0.0367 \\ \text { Metal } & 0.0398 & \text { Wood and Paper } & 0.0360 \\ \text { Wood and Paper } & 0.0276 & \text { Textiles } & 0.0326 \\ \text { Other Manufacturing } & 0.0249 & \text { Metal } & 0.0315 \\ \text { Petroleum \& Chemical } & 0.0246 & \text { Other Manufacturing } & 0.0258\end{array}$

Export as intermediate and final goods from Vietnam to China (top 5 of all sectors, unit: US\$ billion)

$\begin{array}{lrlr}\text { Top 5 sectors } & \text { Value } & \text { Top 5 sectors } & \text { Value } \\ \text { Mining } & 1.71 & \text { Mining } & 3.82 \\ \text { Agriculture } & 0.40 & \text { Agriculture } & 0.77 \\ \text { Machinery } & 0.21 & \text { Food } & 0.35 \\ \text { Textiles } & 0.18 & \text { Textiles } & 0.32 \\ \text { Petroleum \& Chemical } & 0.10 & \text { Machinery } & 0.30\end{array}$

Source: The authors' calculations based on the EORA database.

Note: The input coefficient from the electricity supply sector refers to the monetary unit of electricity intermediate input to produce one unit of final product in each sector. 
2015 has changed from hydropower to natural gas and then to coal. The ratio of coal power in installed capacity rose from $20 \%$ to around $35 \%$ in the 2005-2015 period. Driven by both bilateral trade amount (scale factor) and emission intensity (intensity factor), emission-intensive goods and services exported from Vietnam to China increased during 2005-2015.

China's net $\mathrm{CO}_{2}$ export largely increased in its trade with Vietnam and Indonesia in 2015 (especially in the electricity supply, petrochemical products, and machinery sectors) compared with 2005. On the other hand, it shrank in the trade with Japan (especially in petrochemical products and transportation equipment). Considering China's growing net export of final goods and services during 2005-2015 in these three countries, the shrink of net $\mathrm{CO}_{2}$ export to Japan can be more related to the decrease in domestic emission intensity in China (intensity factor) than changes in export scale (scale factor). As shown in Table 11.5, the direct-emission intensity of the electricity supply sector in China has dropped from 17.01 to 6.28 million $\mathrm{t}-\mathrm{CO}_{2} / \mathrm{US} \$$ billion. In fact, during 2005-2015, the standard coal consumption for power supply in large thermal power plants (above $6000 \mathrm{~kW}$ capacity) in China decreased from 370 to $313 \mathrm{~g} / \mathrm{kWh}$ (China Electricity Council, 2017). Benefiting from the green power generation mix, the emission intensity of the petroleum and

Table 11.5 2005-2015 changes in China: input coefficients from the electricity supply sector and exports from China to Japan

$2005 \quad 2015$

Direct-emission intensity of the electricity supply sector in China (million t- $\mathrm{CO}_{2}$ / US\$ billion)

17.01 6.28

Input coefficients from the electricity supply sector (top 5 of all sectors) in China

Top 5 sectors Value Top 5 sectors Value

$\begin{array}{llll}\text { Mining } & 0.0669 & \text { Mining } & 0.0367\end{array}$

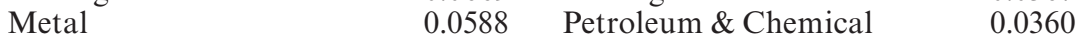

$\begin{array}{llll}\text { Petroleum \& Chemical } & 0.0566 & \text { Metal } & 0.0326\end{array}$

$\begin{array}{llll}\text { Post \& Tele } & 0.0357 \quad \text { Wood and Paper } & 0.0315\end{array}$

$\begin{array}{lll}\text { Wood and Paper } & 0.0329 & \text { Education \& Health }\end{array}$

Export as intermediate and final goods from China to Japan (top 5 of all sectors, unit: US\$ billion)

$\begin{array}{lrlr}\text { Top 5 sectors } & \text { Value } & \text { Top 5 sectors } & \text { Value } \\ \text { Textiles } & 24.77 & \text { Textiles } & 46.83 \\ \text { Machinery } & 17.86 & \text { Machinery } & 39.86 \\ \text { Mining } & 11.79 & \text { Petroleum \& Chemical } & 22.17 \\ \text { Petroleum \& Chemical } & 9.75 & \text { Food } & 16.36 \\ \text { Food } & 8.98 & \text { Transport } & 12.41\end{array}$

Source: The authors' calculations based on the EORA database.

Note: The input coefficient from the electricity supply sector refers to the monetary unit of electricity intermediate input to produce one unit of final product in each sector. 
chemical sector in China also largely decreased, leading to a shrink of its net $\mathrm{CO}_{2}$ export to Japan. It is also worth noting that, the share of mining goods exports from China to Japan dropped in 2015 compared to 2005 (11.2\%$5.8 \%$ ) as shown in Table 11.5, indicating the contribution of changes in trade structure to the reduction in China's $\mathrm{CO}_{2}$ exports.

These results provide two implications. First, the result of domestic sectorlevel emission intensity can reveal which sectors generate higher emissions and pollutants. Second, an increasingly low-carbon power generation mix not only contributes to the national-level emission reduction directly but also helps other sectors reduce emissions (e.g., the petrochemical industry in China, the textile industry in Vietnam in a reverse way). Replacing domestic production with imports of emission-intensive goods does not help reduce global emission. Third, the change in export structure from China to Japan can reduce global emissions as long as it does not cause carbon leakage and relocation of non-power sectors from China to other countries.

Our analysis also shows that the results of the carbon leakage estimation can vary due to the applied approaches to some extent. The differences can be caused by the different approaches, the different definition of non-domestic emissions (e.g., emissions induced by the export of final goods and services in this paper, emissions induced by value added, Meng et al., 2013), and different effort-sharing principles (Höhne et al., 2014; van den Berg et al., 2020). In our analysis, MRIO estimates larger carbon leakages than SRIO. Seven methodologies (i.e., the IPCC, G8, UNDP, OECD, Garnaut, CCCPST, Srensen approach; Ding et al., 2010) have been proposed to establish an international standard, but no consensus has been achieved so far.

This chapter also has some limitations regarding the raw data of the IO tables and emission data. Although the tables from 2005 and 2015 were used in this chapter, they were all compiled using those years' purchase prices. The accuracy of the results could be improved if a table using comparable prices was used. In terms of the raw data on emissions, the results of emissions embodied in trade can be distinguished by sector but cannot be distinguished by energy carrier sources (e.g., by coal and oil) when the current data source is used. In other words, the current results of emissions from the mining sector refer to the emissions generated when coal is produced. It does not represent the emissions caused by the use or consumption of coal. Thus, the results of this chapter are limited in their ability to explore the impacts of coal industry investments.

\section{Conclusions}

In this chapter, we examined whether China has been causing the rise of $\mathrm{CO}_{2}$ emissions among its bilateral trade partners (carbon leakage through trade from China to its bilateral trade partners). We selected four Asian 
countries (Vietnam, Indonesia, India, and Japan) and conducted an examination using two approaches (SRIO and MRIO analyses) in two target years (2005 and 2015).

Among all bilateral trade partners discussed in this chapter, the results show that from 2005 to 2015, the carbon leakage from Japan to China decreased. On the other hand, China increased the domestic $\mathrm{CO}_{2}$ emission and their exports to Vietnam, Indonesia, and India from 2005 to 2015.

Our estimation shows that China's emissions embodied per unit of bilateral trade (namely, how much $\mathrm{CO}_{2}$ emissions are generated per unit of bilateral goods and service trade) has been decreasing from 2005 to 2015. This indicates that more low-emission technologies have been adopted in domestic production activities in China over those ten years. We further looked into input coefficients from the electricity supply sector in all sectors. The improvement in power generation technologies and energy mix not only contributes to the national-level emission reduction directly but also helps other sectors reduce emissions (e.g., the petrochemical industry in China, the textile industry in Vietnam in a reverse way).

Our analysis also suggests using the MRIO approach to incorporate the indirect emissions embodied in the domestic production activities induced by international trade. This can avoid underestimation that would be caused by using the SRIO approach.

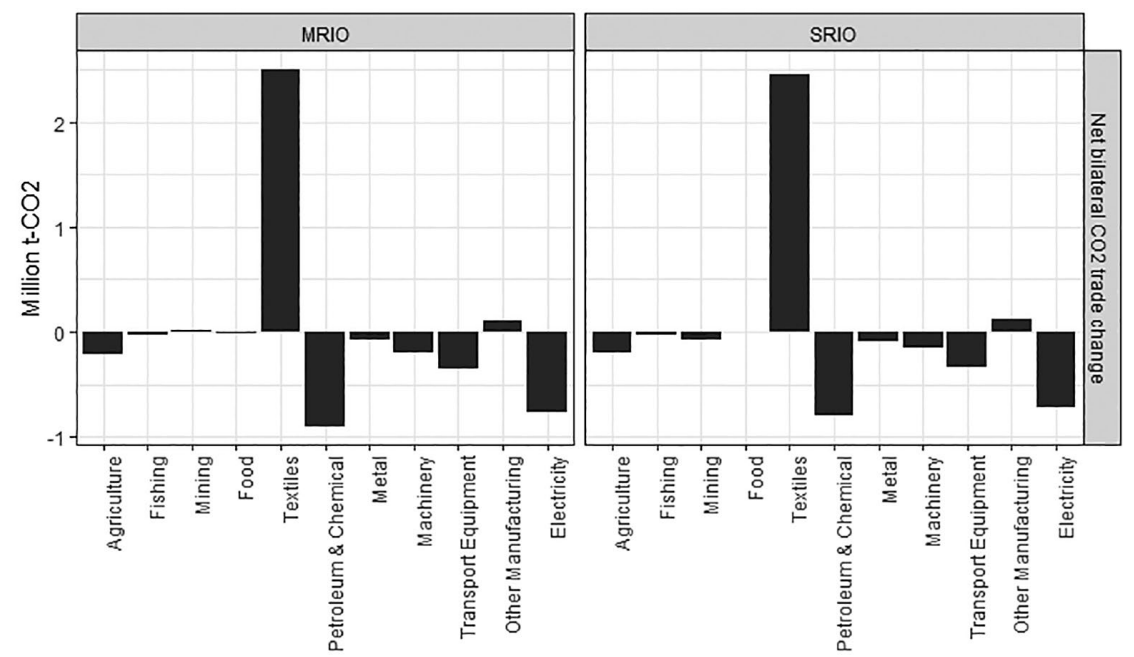

Figure 11.8 Changes from 2005 to 2015 in China's net bilateral $\mathrm{CO}_{2}$ export with Japan at the sector level using the single-region input-output (SRIO) and multi-region input-output (MRIO) approaches.

Source: The authors' calculations based on the EORA database. 


\section{References}

Chen, H., Zou, X., \& Chen, Q. (2011). Export-oriented economy \& environmental pollution in China: The empirical study by simultaneous equation model. Energy Procedia, 5, 884-889. https://doi.org/10.1016/j.egypro.2011.03.156

China Electricity Council. (2017). Annual Development Report on China's Electricity Industry, 2017. Beijing, China.

China Energy Group at Lawrence Berkeley National Laboratory. (2014). Key China Energy Statistics 2014. Lawrence Berkeley National Laboratory.

Cole, M. A. (2004). Trade, the pollution haven hypothesis and the environmental Kuznets curve: Examining the linkages. Ecological Economics, 48(1), 71-81. https://doi.org/10.1016/j.ecolecon.2003.09.007

Copeland, B., \& Taylor, M. (1994). North-South trade and the environment. The Quarterly Journal of Economics, 109(3), 755-787. https://doi.org/10.2307/2118421

Dietzenbacher, E., \& Mukhopadhyay, K. (2007). An empirical examination of the pollution haven hypothesis for India: Towards a green Leontief paradox? Environmental and Resource Economics, 36(4), 427-449. https://doi.org/10.1007/ s10640-006-9036-9

Ding, Z. L., Duan, X. N., Ge, Q. S., \& Zhang, Z. Q. (2010). On the major proposals for carbon emission reduction and some related issues. Science China Earth Sciences, 53(2), 159-172. https://doi.org/10.1007/s11430-010-0012-4

Fan, X., Wu, S., \& Li, S. (2019). Spatial-temporal analysis of carbon emissions embodied in interprovincial trade and optimization strategies: A case study of Hebei. China. Energy, 185, 1235-1249. https://doi.org/10.1016/j.energy.2019.06.168

Gill, F. L., Kuperan Viswanathan, K., Zaini, M., \& Karim, A. (2018). The critical review of the pollution haven hypothesis. International Journal of Energy Economics and Policy, 8(1), 167-174.

Höhne, N., den Elzen \& Escalante, D. (2014). Regional GHG reduction targets based on effort sharing: a comparison of studies. Climate Policy, 14:1, 122-147. https:// doi.org/10.1080/14693062.2014.849452

Jayanthakumaran, K., \& Liu, Y. (2016). Bi-lateral $\mathrm{CO}_{2}$ emissions embodied in Australia-China trade. Energy Policy, 92, 205-213. https://doi.org/10.1016/ j.enpol.2016.02.011

Mani, M., \& Wheeler, D. (1998). In search of pollution havens? Dirty industry in the world economy, 1960 to 1995. Journal of Environment and Development, 7(3), 215-247. https://doi.org/10.1177/107049659800700302

Meng, B., Xue, J., Feng, K., Guan, D., \& Fu, X. (2013). China’s inter-regional spillover of carbon emissions and domestic supply chains. Energy Policy, 61, 1305-1321. https://doi.org/10.1016/j.enpol.2013.05.108

Shahbaz, M., Nasreen, S., Abbas, F., \& Anis, O. (2015). Does foreign direct investment impede environmental quality in high-, middle-, and low-income countries? Energy Economics, 51, 275-287. https://doi.org/10.1016/j.eneco.2015.06.014

Taylor, B. R. C., \& M. S. (2004). Trade, growth, and the environment. Journal of Economic Literature, XLII (March), 7-71

Temurshoev, U. (2011). Pollution haven hypothesis or factor endowment hypothesis: Theory and empirical examination for the US and China. SSRN Electronic Journal. https://doi.org/10.2139/ssrn.1147660 
van den Berg, N.J., van Soest, H.L., Hof, A.F. et al. (2020). Implications of various effort-sharing approaches for national carbon budgets and emission pathways. Climatic Change, 162, 1805-1822. https://doi.org/10.1007/s10584-019-02368-y

Wiebe, K., \& Yamano, N. (2016), Estimating $\mathrm{CO}_{2}$ Emissions Embodied in Final Demand and Trade Using the OECD ICIO 2015: Methodology and Results, OECD Science, Technology and Industry Working Papers, No. 2016/05, OECD Publishing, Paris. https://doi.org/10.1787/5jlrcm216xkl-en

World Bank. (2011). GDP per capita (constant 2010 US\$). https://data.worldbank. org/indicator/NY.GDP.PCAP.KD

Yang, H. Y. (2001). Trade liberalization and pollution: A general equilibrium analysis of carbon dioxide emissions in Taiwan. Economic Modelling, 18(3), 435-454. https://doi.org/10.1016/S0264-9993(00)00048-1

Table 11.A Sectors

\begin{tabular}{rll}
\hline No. & Sector & Sector abbreviation \\
\hline 1 & Agriculture & Agriculture \\
2 & Fishing & Fishing \\
3 & Mining and Quarrying & Mining \\
4 & Food \& Beverages & Food \\
5 & Textiles and Wearing Apparel & Textiles \\
6 & Wood and Paper & Wood and Paper \\
7 & Petroleum \& Chemical & Petroleum \& Chemical \\
8 & Metal Products & Metal \\
9 & Electrical and Machinery & Machinery \\
10 & Transport Equipment & Transport Equipment \\
11 & Other Manufacturing & Other Manufacturing \\
12 & Recycling & Recycling \\
13 & Electricity, Gas and Water & Electricity \\
14 & Construction & Construction \\
15 & Maintenance and Repair & Maintenance \\
16 & Wholesale Trade & Wholesale Trade \\
17 & Retail Trade & Retail Trade \\
18 & Hotels and Restaurants & Hotels \& Restaurants \\
19 & Transport & Transport \\
20 & Post and Telecommunications & Post \& Tele \\
21 & Financing & Financing \\
22 & Public Administration & Public Administration \\
23 & Education, Health and Other Services & Education \& Health \\
24 & Private Households & Private Households \\
25 & Others & Others \\
26 & Re-export \& Re-import & Re-export \& Re-import \\
\hline & & \\
\hline & EoRA & \\
\hline
\end{tabular}

Source: EORA database. 